\title{
Reply to 'Evidence for simple volcanic rifting not complex subduction initiation in the Laxmi Basin'
}

\author{
Dhananjai K. Pandey (10 ${ }^{1 凶}$, Anju Pandey ${ }^{2} \&$ Scott A. Whattam (i) ${ }^{3}$ \\ REPLYING to Clift et al. Nature Communications https://doi.org/10.1038/s41467-020-16569-y (2020)
}

Pits andey et al. ${ }^{1}$ proposed relict subduction initiation in the Laxmi Basin (LB) as a viable alternative to numerous competing tectonic models for the evolution of western Indian margin. We thank Clift et al. ${ }^{2}$ for their interest in our study. They contend that basalts from volcanic rifted margins may also exhibit analogous geochemical signatures. However, we do not agree with their views for several reasons.

Clift et al. ${ }^{2}$ argue that enrichments in certain elements such as $\mathrm{Th}, \mathrm{U}, \mathrm{Pb}$ and $\mathrm{Sr}$, typical of subduction magmatism, may also imply possible crustal assimilation. However, they ${ }^{2}$ overlooked the extent of such enrichments. In fact, the scale of Th enrichments for both lava types differ almost by an order of magnitude ${ }^{2}$. Low average $\mathrm{Th} / \mathrm{Yb}$ ratios for $\mathrm{LB}(\sim 0.2)$ are linked to a shallower source, e.g., mid-ocean ridge basalt (MORB), similar to subduction related ophiolites ${ }^{3}$. In contrast, rifted margin basalts exhibit much higher $\mathrm{Th} / \mathrm{Yb}$ ratios $(>1)$ pointing at much deeper sources e.g., ocean island basalts. Similarly, $\mathrm{TiO}_{2} / \mathrm{Yb}$ vs. $\mathrm{Nb} / \mathrm{Yb}$ systematics $^{2}$ of the LB and IBM forearc both overlap significantly with notably low $\mathrm{TiO}_{2}$ contents-distinct from volcanic margin basalts.

Clift et al. $^{2}$ further state that $\mathrm{Nd} / \mathrm{Sr}$ isotopes may indicate continental input instead of subduction initiation $(\mathrm{SI})^{1}$ during its petrogenesis. Their contention is, however, inconsistent when examined with existing isotopic data. Average $\varepsilon N d$ values ${ }^{4}$ of lower and upper continental crust are -10 and -20 respectively while global subducting sediments (GLOSS) is restricted below -5 . In contrast, LB lavas, having $\varepsilon N d$ values between +6 to +8 , are very close to Depleted Mantle. Moreover, average Ba concentrations of continental crust, LB lava and Muslim Bagh ophiolites are $\sim 259,140$ and $110 \mathrm{ppm}^{4}$ respectively ${ }^{4}$. Therefore, isotopic, total trace and rare earth elements (REE) characteristics of LB lava are akin to SI, instead of volcanic margins. Although Clift et al. ${ }^{2}$ did not include isotopic data for comparison, we suspect that the ${ }^{87} \mathrm{Sr} /{ }^{86} \mathrm{Sr}$ values from rifted volcanic margins would be significantly higher than the modest LB lava values (7037-0.7044), which are similar to Neotethyan ophiolites and forearc lavas ${ }^{1}$.

Highly mobile elements (e.g., Rb, Sr, Ba, U) are concentrated into aqueous slab-derived fluids, whereas Th and other light rare earth elements (LREE) are partitioned into sediment-derived melts ${ }^{5-7}$. Enrichment in $\mathrm{Ba}$ and to minor extent Th again points towards SI. Similarly, Ba/Th vs. Th variations ${ }^{1}$ show evidence of shallow, fluidderived enrichments ${ }^{8}$. Using unaltered MORB dataset of Jenner and $\mathrm{O}^{\prime} \mathrm{Neill}^{9}$, one can clearly see enrichment of Ba in LB lava relative to MORB. Often $\mathrm{Sr}$ and $\mathrm{Ba}$ additions can result from seawater hydrothermal alteration processes, however LB lavas show no discernible correlation between $\mathrm{Sr}, \mathrm{Ba}$ and Loss on ignition $\left(R^{2}=0.01\right.$ for both). In fact, samples with the lowest loss on ignition values, exhibit the highest $\mathrm{Ba}$. This implies that the high $\mathrm{Ba}$ relative to MORB of the LB lavas, similar to the Muslim Bagh ophiolite, is a primary feature of LB lavas and the result of shallow slab-derived fluid input and not seawater alteration.

The most important distinction between LB and volcanic margin basalts come from REE signatures, which Clift et al. have ignored $^{2}$. LB lavas exhibit highly depleted LREEs and low total REEs in contrast to volcanic margin lava (see Fig. 1). Crustal inputs at volcanic margins typically result in significantly elevated concentrations of large ion lithophile elements and LREEs, which are absent in LB (Fig. 1). A plot of chondrite normalized [La/Yb $]_{N}$ ratios vs. $\mathrm{SiO}_{2}$ (Fig. 2) also highlights differences with significantly higher $[\mathrm{La} / \mathrm{Yb}]_{N}$ values for North Atlantic Igneous Province lavas ( 0.6 to as high as 30$)$ in comparison to LB lavas $(\sim 0.6-1.4)$. The lack of LREE enrichments in LB lava (similar to forearc basalts of the IBM with $[\mathrm{La} / \mathrm{Yb}]_{N}$ less than 1.4$)$ is therefore noteworthy. Furthermore, boninitic-like lava from LB exhibit characteristic Ushaped REE profiles which are primarily attributed to protoforearc and forearc environments ${ }^{10}$.

Further, $\mathrm{TiO}_{2}$ is among the least mobile elements and compared to other trace elements, solubility of $\mathrm{TiO}_{2}$ is very low in common mantle or subduction zone fluids. $\mathrm{TiO}_{2}$ concentrations may depend on the rate of crystallization of $\mathrm{Fe}-\mathrm{Ti}$ phases. With respect to high LREE, $\mathrm{Th} / \mathrm{Yb}$ and enrichment of $\mathrm{Ti}$, we argue that the LREE (and HREE) enrichments relative to MREE seen in Ushaped REE profiles is typical of boninitic-like lavas and is not related to crustal contamination or alteration.

Prior studies from this region envisaged numerous intraoceanic weak zones at $\sim 70 \mathrm{Ma}$ (see Pandey et ${ }^{1} .^{1}$ ). Rapid northward drift of India coupled with frequent rotations since the

\footnotetext{
${ }^{1}$ National Centre for Polar \& Ocean Research, Ministry of Earth Sciences, Vasco da Gama, Goa 403804, India. ${ }^{2}$ H-V-3, NCPOR Campus, Vasco da Gama, Goa 403804, India. ${ }^{3}$ Department of Geosciences, King Fahd University of Petroleum \& Minerals, Dhahran 31261, Saudi Arabia. ${ }^{凶}$ email: pandey@ncpor.res.in
} 

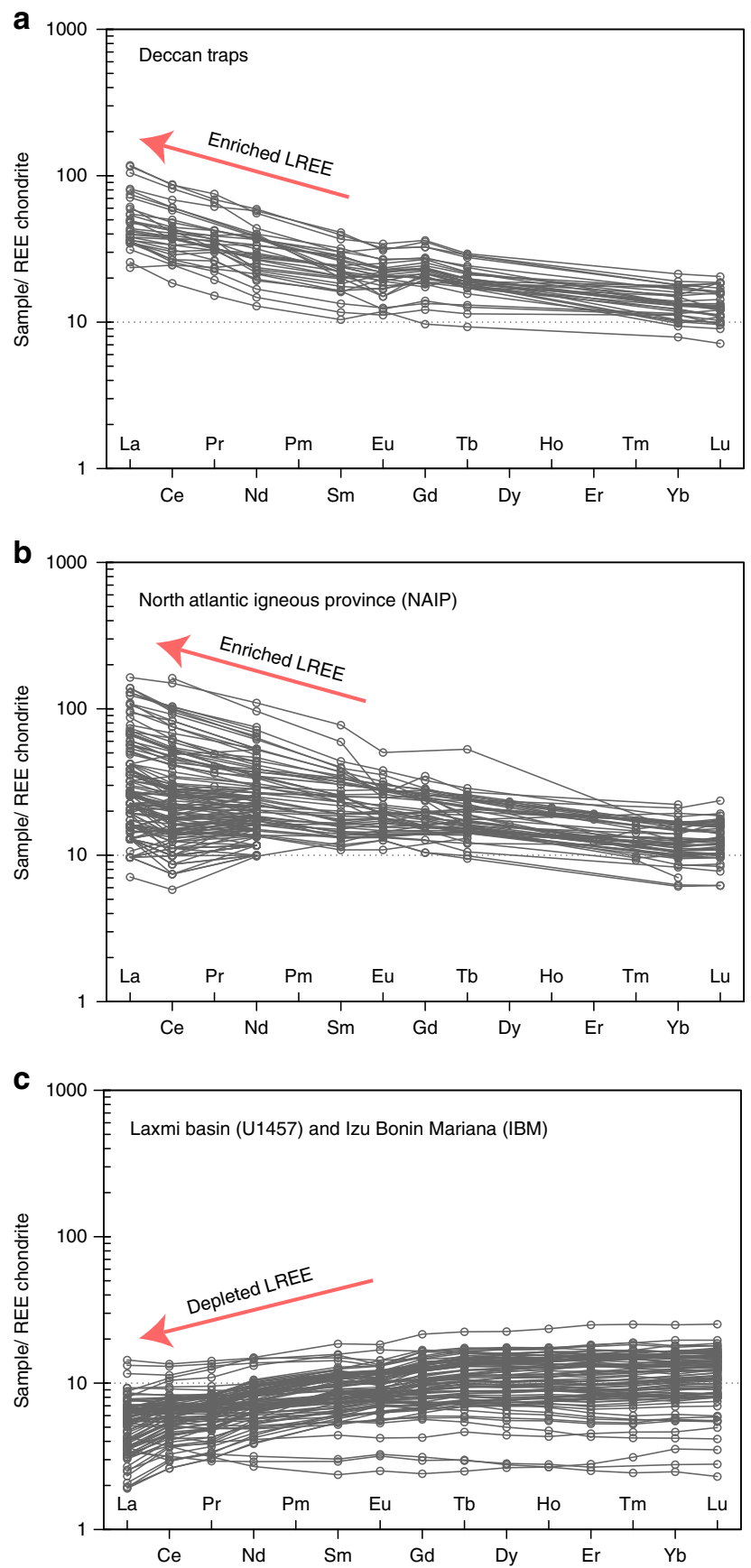

Fig. 1 REE variations of different lava types. Chondrite-normalized rare earth element variations of different lava types. a-c The above diagram highlights characteristic differences among lavas from different tectonic regimes as labelled. Arrows indicate general enrichment/depletion trends. (See Pandey et al. ${ }^{1}$ and Clift et al. ${ }^{2}$ for various data sources).

late Cretaceous period is well established. After its spectacular journey from the southern latitudes, India presently resides in the northern hemisphere. Accordingly, considerable amount of missing/unaccounted for crust in the NW Indian Ocean inferred by kinematic modelling implies synchronous compressional tectonics in this region (see Pandey et al. ${ }^{1}$ ).

Clift et al. ${ }^{2}$ 's comments are largely drawn from a particular school of thoughts based on indirect geophysical models proposed well before drilling in LB in 2015. Using same regional seismic profiles ${ }^{11-13}$ different groups interpret Laxmi ridge and basin variably either as continental/oceanic crust. Equivocal
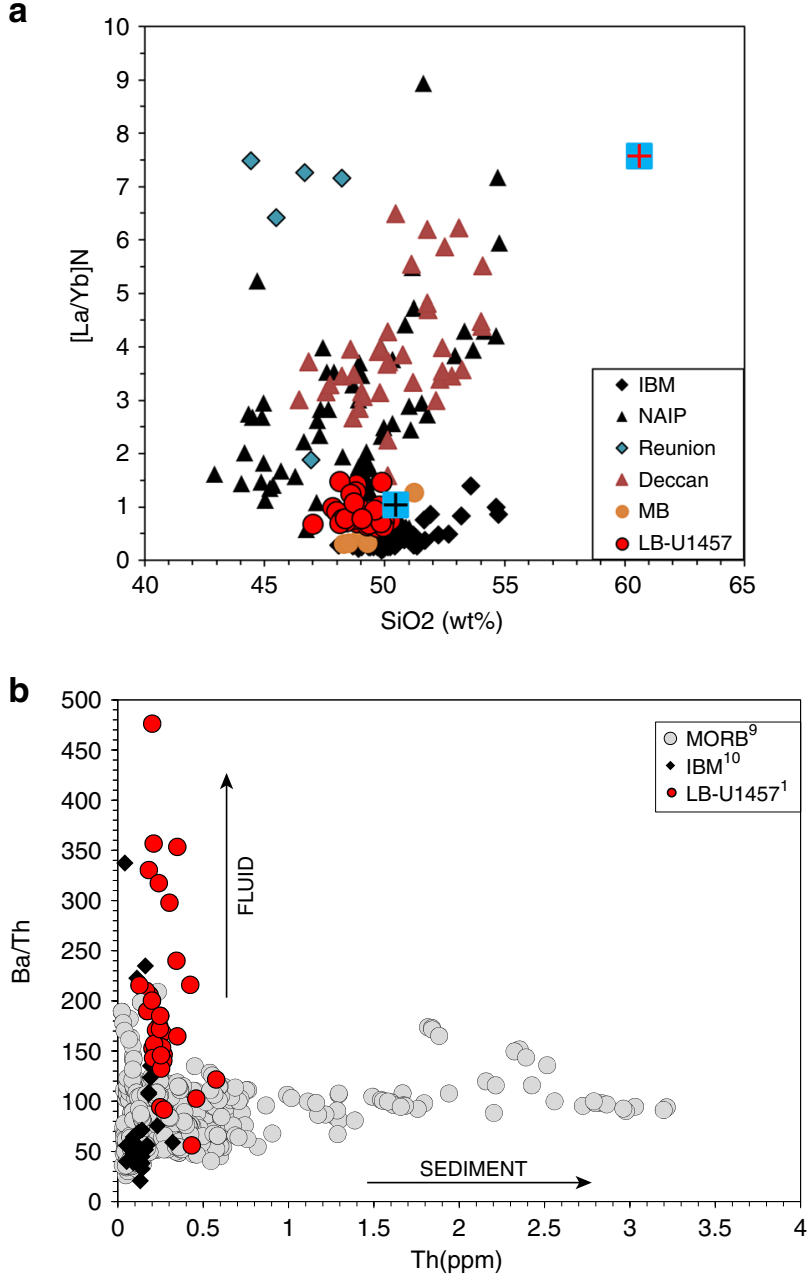

Fig. 2 Role of hydrous fluids in LB lava. Characteristic geochemical diagrams. a Plot of chondrite normalized $[\mathrm{La} / \mathrm{Yb}]_{N}$ ratios vs. $\mathrm{SiO}_{2}$ for different lava types. The black and red ' + ' signs embossed in blue squares represent mid-ocean ridge basalt (MORB) ${ }^{9}$ and bulk continental crust ${ }^{4}$ ratios respectively. $\mathbf{b} \mathrm{Ba} / \mathrm{Th}$ vs. Th abundances for $\mathrm{LB}$ lava to evaluate role of hydrous fluids versus sediments during subduction process. High $\mathrm{Ba} / \mathrm{Th}$ values with low Th abundances are widely attributed to preferential mobilization of large ion lithophile elements (LILEs e.g., Ba) through hydrous fluids components (vertical array) as opposed to the sediment flux (horizontal array) from the downgoing slab. IBM: Izu-Bonin-Mariana; NAIP: North Atlantic igneous province; MB: Muslim Bagh. (See Pandey et al. ${ }^{1}$ and Clift et al. ${ }^{2}$ for various data sources).

crustal models remained inconclusive about whether this margin is a magma rich or magma poor type. Likewise, sporadic intrabasement magmatic reflections on seismic profiles are interpreted as seaward dipping reflectors (SDR)/axial anomalies/extinct spreading centres/volcanic flows/ intrusives etc ${ }^{1,11-13}$. No precise knowledge is available regarding basin-wide extent of SDRs in the $\mathrm{LB}$, in contrast to what is reported by Clift et $\mathrm{al}^{2}$. Therefore, a sweeping portrayal ${ }^{2}$ of SDRs in LB and surrounding regions appears to be conjectural.

Identification of a proto-trench would require detailed morphological and crustal imaging of the region, in time and space, which was beyond the scope of Pandey et $\mathrm{al}^{1}$. Clift et $\mathrm{al}^{2}$ further link formation of the Laxmi ridge to that of the Saurashtra Volcanic Province. Due to inconclusive interpretations and lack of any samples/rocks/data from both regions, we prefer not to speculate about its precise affinity. However, geochemical signatures of LB lava are categorically different from that of Deccan volcanics ${ }^{14}$. 
Two-dimensional flexural modeling primarily dealt with postrift evolution of the LB (awaiting geochemical results from Site U1457) and confirmed significant residual bathymetry in LB and surrounding regions $(\sim 2-3 \mathrm{~km}$ at $\sim 61 \mathrm{Ma})$. This means that any prior magmatism must have occurred under considerably deepwater settings, in consonance with shipboard observations about rapid quenching of the $\mathrm{LB}$ basalts after their emplacement. Regional crustal uplift however, would depend upon several factors including the onset, extent and duration of the impingement of a potential thermal regime.

Finally, we would like to conclude by pointing out that our study ${ }^{1}$ reports direct data from LB through crustal sampling for the first time. Geochemical and isotopic imprints of LB lava distinctly imply relict subduction initiation. Therefore, new findings based on direct observations cannot be undermined merely to support specific geophysical models. Indeed, additional regional basement sampling, radiometric dating and revised plate kinematic modelling would provide important insights about the complexity of the western Indian margin.

\section{Data availability}

No new data are reported in this manuscript. See Pandey et al. ${ }^{1}$ and Clift et al. ${ }^{2}$ for data sources related to Fig. 1 and 2.

Received: 28 August 2019; Accepted: 7 May 2020;

Published online: 01 June 2020

\section{References}

1. Pandey, D. K., Pandey, A. \& Whattam, S. A. Relict subduction initiation along a passive margin in the northwest Indian Ocean. Nat. Commun. 10, 2248 https://doi.org/10.1038/s41467-019-10227-8 (2019).

2. Clift, P. et al. Evidence for simple volcanic rifting not complex subduction initiation in the Laxmi Basin. Nat. Commun. https://doi.org/10.1038/s41467020-16569-y (2019).

3. Whattam, S. A. \& Stern, R. The "subduction initiation rule": a key for linking ophiolites, intra-oceanic arcs and subduction initiation. Contributions Mineral. Petrol. 162, 1031-1045 (2011).

4. Rudnick, R. \& Gao, S. in Composition of the Continental Crust. (ed Rudnick, R. L.) 1-64 (Treat, Geochm, 2005).

5. Elliott, T. et al. Element transport from slab to volcanic front at the Mariana arc Jour. Geophys. Res. 102, 14991-15019 (1997).

6. Hawkesworth, C. et al. Elemental $U$ and $T h$ variations in island arc rocks: implications for U-series isotopes. Chem. Geol. 139, 207-221 (1997)

7. Singer, B. S. et al. Along-strike trace element and isotopic variation in Aleutian Island Arc basalt: subduction melts sediments and dehydrates serpentine. Jour. Geophys. Res 112, B06206 (2007).

8. Pearce, J. A. et al. Geochemical mapping of the Mariana arc-basin system: implications for the nature and distribution of subduction components. Geochem., Geophysics, Geosystems 6, Q07006 (2005).
9. Jenner, F. E. \& O’Neill, H. S. C. Analysis of 60 elements in 616 ocean floor basaltic glasses. Geochem. Geophys. Geosyst. 13, Q02005 (2012).

10. Reagan, M. K. et al. Fore-arc basalts and subduction initiation in the IzuBonin-Mariana system. Geochem. Geophys. Geosyst. 11, Q03X12 (2010).

11. Corfield, R. I. et al. Variability in the crustal structure of the West Indian Continental Margin in the Northern Arabian Sea. Pet. Geosci. 16, 257-265 (2010).

12. Calvès G. et al. Seismic volcanostratigraphy of the western Indian rifted margin: the pre-Deccan igneous province. J. Geophys. Res. Solid Earth 116, https:// doi.org/10.1029/2010JB000862. (2011).

13. Misra, A. A., Sinha, N. \& Mukherjee, S. Repeat ridge jumps and microcontinent separation: insights from NE Arabian Sea. Mar. Pet. Geol. 59, 406-428 (2015).

14. Melluso et al. Constraints on the mantle sources of the Deccan Traps from the petrology and geochemistry of the basalts of the Gujarat state, western India. J. Petrol. 36, 1393-1432 (1995).

\section{Acknowledgements}

DP acknowledges financial support from the Ministry of Earth Sciences (MoES), India bearing Grant number: MoES/PO(Seismo)/3(45)2012. This is NCPOR contribution number \#J-03/2020-21.

\section{Author Contributions}

All authors (D.P., A.P. and S.W.) contributed to the discussion of the content of this manuscript.

\section{Competing interests}

The authors declare no competing interests.

\section{Additional information}

Correspondence and requests for materials should be addressed to D.K.P.

Peer review information Nature Communications thanks Cathy Busby and the other, anonymous, reviewer(s) for their contribution to the peer review of this work.

Reprints and permission information is available at http://www.nature.com/reprints

Publisher's note Springer Nature remains neutral with regard to jurisdictional claims in published maps and institutional affiliations.

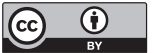

Open Access This article is licensed under a Creative Commons Attribution 4.0 International License, which permits use, sharing, adaptation, distribution and reproduction in any medium or format, as long as you give appropriate credit to the original author(s) and the source, provide a link to the Creative Commons license, and indicate if changes were made. The images or other third party material in this article are included in the article's Creative Commons license, unless indicated otherwise in a credit line to the material. If material is not included in the article's Creative Commons license and your intended use is not permitted by statutory regulation or exceeds the permitted use, you will need to obtain permission directly from the copyright holder. To view a copy of this license, visit http://creativecommons.org/ licenses/by/4.0\%

(C) The Author(s) 2020 